\title{
Weed Flora and Nutritional Composition of Cowpea Grains as Influenced by Some Pre Emergence Herbicides Application in Nigeria
}

\author{
Omovbude, S. ${ }^{*} \quad$ Remison, S.U. ${ }^{2} \quad$ Omoregie, A.U ${ }^{2}$ \\ 1.Department of Crop and Soil Science, University of Port Harcourt, East West Road, Choba P.M.B, 5323, \\ Port Harcourt, Nigeria \\ 2. Department of Crop Science, Ambrose Alli University, Ekpoma, Edo State, Nigeria
}

\begin{abstract}
Field experiment was conducted at the Teaching and Research Farm of Ambrose Alli University, Ekpoma, Edo. State, Nigeria to the evaluate influence of some pre emergence herbicides application on weed flora and nutritional composition of cowpea grains. The treatments consisted of no weeding (control), Coda gold ${ }^{\circledR}$ at 1.65 $\mathrm{kg}$ a.i./ha, Galex at $3.0 \mathrm{~kg}$ a.i./ha, Pendilin at $2.0 \mathrm{~kg}$ a.i./ha, One hoe weeding at 3 weeks after planting (WAP) and Two hoe weeding at $3 \&$ 7WAP laid out in a Randomized Complete Block Design (RCBD) with four replicates. The result showed that there were changes in weed flora composition of broadleaved weeds and grasses except sedges before and after experiment. For instance, approximately $52.38 \%$ of the weeds were broadleaved species and $28.57 \%$ were grasses before planting while about $38.1 \%$ of the weeds were broadleaved species and $42.86 \%$ grasses after harvest. Before planting, annual weed species were $28.57 \%$ and perennial $71.43 \%$ while after harvest, annual weed species were $47.62 \%$ and perennial $52.39 \%$. The result further showed that plot treated with herbicides had a slight increase in nutritional composition of cowpea grains when compared to hoe weeding and no weeding. Since, the herbicides used in the study altered weed flora composition of cowpea plant without having any adverse effect on the nutritional composition of the grains, they are recommendable to farmers for boosting cowpea production in Nigeria.
\end{abstract}

Keywords: cowpea grains, nutritional composition, pre emergence herbicides, weed flora, DOI: $10.7176 / \mathrm{JBAH} / 9-2-05$

\section{INTRODUCTION}

Cowpea (Vigna unguiculata (L.) Walp) is a leguminous crop that belongs to family of Fabaceae. According to Adegbite and Amusa (2008) Nigeria produced 2.1 million tonnes of cowpea out of the estimated 3.3 million tonnes produced globally in year. This figure ranked Nigeria as world's largest producer, followed by Niger (650,000 tonnes) and Mali (110,000 tonnes). In Nigeria, cowpea is commonly cultivated in the northern savannah and recently; its cultivation is gradually gaining recognition in the southern parts of Nigeria as result of its economic benefits (Patuibikunle and Smith, 2008). Arubalueze et al. (2018) reported that almost all parts of the plant are important; the seeds are major source of plant protein and vitamins for man, the fodder serves as feed for animals and a source of income to farmers. The young leaves and immature pods are eaten as vegetables (Dugje et al., 2009) Average yield of cowpea (0.42t/ha) is low in Nigeria (Singh et al., 2002) when compared to achievable average yield that ranged from $1.50 \mathrm{t} / \mathrm{ha}$ to $3.00 \mathrm{t} / \mathrm{ha}$ (Dzemo et al., 2010). Many researchers have shown that weeds account for cowpea yield losses (Osipitan et al., 2016; Ugbe et al., 2016). The authors reported that yield loss under weedy conditions is between $25 \%$ and $76 \%$ depending on the variety and ecology.

Weeds are plants that grow in a place where they are not wanted and their composition differed as results of many factors among these factors is weed control strategies. Weed species composition provides an estimate of herbicide effectiveness for controlling weeds in crops. Kumar Sit et al. (2007) reported that information of weed flora gives perception on the use of herbicides and in formulation of appropriate management strategies. Consequently, the knowledge of weed flora associated with cowpea is a fundamental tool for controlling weeds in cowpea. For effective and efficient weed control of cowpea production in Nigeria, farmers, employ various weed control methods including herbicide usage. Sufficient Information exists on the impact of herbicides on cowpea yield in Nigeria from literature. However, information on the effect of herbicides on weed flora and nutritional composition of cowpea grains are scanty in Nigeria. Hence, the objective of the study was to evaluate the influence of some pre emergence herbicides on weed flora and nutritional composition of cowpea grain

\subsection{MATERIALS AND METHODS}

2.1 Description of the Experimental Site

The experiment was conducted at the Teaching and Research Farm of Ambrose Alli University, Ekpoma, Edo. State, Nigeria. Ekpoma is located between latitude $6^{\circ} 45^{\prime}$ North and longitude $6^{\circ} 8^{\prime}$ East and lies within the rainforest savanna- transition zone of Edo State. The climatic condition of Edo State is similar to other parts of southern Nigeria. There are two distinct seasons, the dry season and the rainy season. The rainfall distribution 
follows a bimodal pattern with the first rainy season starting from March to July and the second season from August to November. A 20 -year annual average of rainfall is about $1200 \mathrm{~mm}$ per year (Remison, 2004). It has a warm climate with minimum and maximum temperatures of $20^{\circ} \mathrm{C}$ and $30^{\circ} \mathrm{C}$ respectively (Ighalo et al., 2008)

\subsection{Soil analysis}

Soil samples were collected at a uniform depth of 0-15 cm from the experimental area with an auger before experiment. The soil samples were bulked to form a composite sample. The physico-chemical properties of the soil were carried using standard procedure (IITA, 1982).

\subsection{Cowpea used}

The cowpea variety used for the study was Ife brown. The grains were purchased from the International Institute of Tropical agriculture (IITA), Ibadan, Nigeria. It is an early maturing variety with medium duration. It has rough, brown seeds, which are relatively large.

\subsection{Experimental design and treatments}

The experiment was laid out as a Randomized Complete Block Design (RCBD) with six (6) treatments replicated four times. The treatments consisted of no weeding (control), Coda gold ${ }^{\circledR}$ at $1.65 \mathrm{~kg}$ a.i./ha, Galex at $3.0 \mathrm{~kg}$ a.i./ha, Pendilin at $2.0 \mathrm{~kg}$ a.i./ha, One hoe weeding at 3 weeks after planting (WAP) and Two hoe weeding at $3 \& 7$ WAP.

\subsection{Cultural details}

Experimental land area of $23 \mathrm{~m} \mathrm{x} 19 \mathrm{~m}\left(437 \mathrm{~m}^{2}\right)$ of approximately 0.04 ha was manually cleared, stumps and debris were packed. The experimental area was divided into four blocks while each block was further divided into six (6) plots making it 24 plots. Each plot size was $3 \mathrm{~m} \mathrm{x} 4 \mathrm{~m}$. The plots were separated by $1 \mathrm{~m}$ while the blocks were separated with a pathway of $1 \mathrm{~m}$. The dominant weed species found in the experimental site and their level of occurrence are presented in Table 2. Planting of cowpea was done at spacing of $60 \mathrm{~cm} \times 25 \mathrm{~cm}$. Two seeds were planted per hole and the seedlings thinned to one stand at 2 WAP, giving a desired population of $66667 \mathrm{plant} / \mathrm{ha}$. No fertilizer was applied to the crop stands. One day after planting, 12 plots were sprayed with the specific rate of individual herbicides using CP3 knapsack sprayer calibrated to deliver approximately 250 $\mathrm{L} /$ ha at $210 \mathrm{kpa}$ with a red polijet nozzle swath width $1 / 2 \mathrm{~m}$. The first weeding was done by hoeing at $3 \mathrm{WAP}$ and the second weeding at 7WAP. Harvesting was carried out when half of the pods were mature (when they turned brown). The pods were handpicked from each net plot, threshed, winnowed and sun dried for one week.

\subsection{Data collection}

\subsubsection{Weed data}

The weed growth parameters measured were common weed species present before and at the end of the experiment done by visual rating. Species were identified using weed album (Akobundu and Agyakwa, 1987).

\subsubsection{Nutritional composition data}

The dry cowpea grains from four replicates were bulked per treatment for mineral and proximate composition of the grains. The mineral and proximate compositions were determined using the method of AOAC (1990).

\subsection{RESULTS}

\subsection{Soil physico-chemical properties}

Some of the physicochemical properties of the soil before planting are presented in Table 1. The soil was slightly acidic; moderate in organic carbon; low in total nitrogen; high in available Phosphorus (P), Calcium $(\mathrm{Ca})$, and Magnesium $(\mathrm{Mg})$, Potassium $(\mathrm{K})$ and Sodium $(\mathrm{Na})$

\subsection{Weed flora assessment}

\subsubsection{Weed flora before the experimentation}

Table 2 shows the weeds flora observed on the experimental site before planting and their levels of infestation. Twenty one (21) weeds species belonging to 19 genera and 9 families were found in the experimental site before planting. About $28.57 \%$ of all the weed species belonged to the Poaceae (6), $28.57 \%$ Cyperaceae (4) and $19.05 \%$ Asteraceae (3) 14.29\%. Others were Fabaceae (2) 9.52\%, Malvaceae (2) 9.52\%, Amaranthaceae (1) 4.76\%, Euphorbiaceeae (1) 4.76\%, Portulacaeae (1) 4.76\% and Solanaceae (1) 4.76\%. Approximately 52.38\% of the weeds were broadleaved species, $28.57 \%$ were grasses while $19.05 \%$ were sedges. Annual weed species recorded were $28.57 \%$ while perennial weed species were $71.43 \%$. The most dominant weed species found at the experimental site were: Aspilia africana, Euphorbia heterophylla, Mucuna pruriens, Cyperus esculentus and Cyperus rotundus. 


\subsubsection{Weed flora after the experimentation}

The weed flora observed at the experimental site and their level of infestation under the each treatments after harvest are presented in Table 3. Twenty one (21) weeds species belonging to 19 genera and 9 families were found in the experimental site at harvest. About $42.86 \%$, of all the weed species belonged to the Poaceae (9), $28.57 \%$ Cyperaceae (4) and 19.05\% Asteraceae (3) 14.29\%. Others were Fabaceae (2) 9.52\%, Euphorbiaceeae (1) $4.76 \%$, Malvaceae (1) $4.76 \%$ and Solanaceae (1) $4.76 \%$. Approximately $38.1 \%$ of the weeds were broadleaved species, $42.86 \%$ were grasses while $19.05 \%$ were sedges. Annual weed species recorded $47.62 \%$ while perennial weed species recorded $52.39 \%$. The most dominant weed species present in unweeded plots at harvest were: Ageratum conyzoides, Chromolaena adorata, Cyperus rotundus, Echinochloa colona, Imperata cylindrical, Rottboellia cochinchinesis. Most dominant weed species present in weeding once plot were Erigeron floribundus and Imperata cylindrica while Erigeron floribundus was the only dominant weed specie in plots that were weeded twice. Four new weed species were found at harvest namely: Echinochloa colona, Chloris pilosa, Erigeron floribundus and Euphorbia heterophylla

\subsection{Nutritional composition of cowpea grains}

The effect of pre emergence herbicides on proximate and mineral composition of cowpea grain is presented in Table 4. The proximate composition showed that the crude protein content of the cowpea grain ranged from $15.27 \%$ in no weeding to $23.40 \%$ in Codal gold ${ }^{\circledR}$ with a mean crude protein content of $20.41 \%$. In other food substances, the lipid content of the grain ranged from $1.26 \%$ to $1.96 \%$ with a mean of $1.57 \%$, Ash content ranged from 2.45 to $3.40 \%$ with a mean of $3.07 \%$, crude fibre ranged from $3.20 \%$ to $3.91 \%$ with a mean of $3.71 \%$ and carbohydrate content ranged from $56.00 \%$ to $56.81 \%$ with a mean of $56.62 \%$.

Mineral composition of the grains showed that $\mathrm{N}$ (Nitrogen) ranged from $480 \mathrm{mg} / 100 \mathrm{~g}$ to $517 \mathrm{mg} / 100 \mathrm{~g}$ with a mean of $500 \mathrm{mg} / 100 \mathrm{~g}$. While P (Phosphorus) ranged from $441 \mathrm{mg} / 100 \mathrm{~g}$ to $463 \mathrm{mg} / 100 \mathrm{~g}$ with a mean of $453 \mathrm{mg} / 100 \mathrm{~g}$ and $\mathrm{K}$ (Potassium) ranged from $1201 \mathrm{mg} / 100 \mathrm{~g}$ to $1261 \mathrm{mg} / 100 \mathrm{~g}$ with a mean of $1243 \mathrm{mg} / 100 \mathrm{~g}$.

\subsection{DISCUSSION}

Nitrogen level was deficient and inadequate in the soil from the experimental site because it value was below the critical level of $0.15 \%$ while those of other nutrient elements were adequate (Ibude et al., 1988). The probable reason for the deficiency of nitrogen might be due to intensive cultivation of the experimental site. The observed difference between the weed species before planting and after harvest might be attributed to weed control emanating from treatment application (Hyvonen and Salonen, 2002). The difference in weed species composition could also be attributed to periodicity of weeds. Herbicides markedly alter the composition of weed communities in terms of relative abundance of species (Cousens and Mortimer, 1995).

Weed persistent was more in no weeding plots due to non-application of treatment. Plot treated with Codal gold ${ }^{\circledR}$ was less persistent to weeds when compared to other herbicides probable because of it inherit characteristic as a broad weed spectrum of broadleaved, grasses and sedges. The new weed species found at harvest were probably pre -adapted weeds (Avav and Uza, 2002). The frequent re- occurrences of weeds on hoe weeded plots were due to their growth habit. Disturbance of the topsoil by hoeing exposes the weed seeds to rapid germination emergence condition (Akobundu, 1987). Rottboellia cochinchinesis was the most common weeds in all the treatments. This might be attributable to the fact that it has the capacity to exhibit successional germination throughout the growth period of cowpea.

The variations noted in the nutritional composition could be due to treatments effect on weed infestation. The study observed that weed infestation was high in no weeding plot when compared to other treatments plot and this high weed infestation could have probable reduced the nutritional quality of the grains. The contents of food type namely: crude protein, lipid, crude ash, crude fibre and carbohydrate were slightly increased in Coda gold ${ }^{\circledR}$, Galex and Pendilin treated cowpea plots when compared to unweeded and hoe-weeded plots probably as result of low to moderate weed infestation. In the same vein, mineral level of nitrogen, phosphorous and potassium were slightly higher in herbicides treated plots than unweeded and hoe-weeded plots.

Audus (1980) noted that mechanism of herbicides of not interfering with nutritional composition of crops is still under investigation. Generally, the values of the proximate and mineral analysis of the cowpea grains felled within the range reported by Oyenuga (1968). Chen (1985) noted that treatment of cowpea plant with pendimethalin and metubromuron enhanced the level of reducing sugar, total soluble carbohydrate, lipid, and proteins. Alonge et al. (1997) also reported that the application of a mixture of metolachlor and metobromuron (Galex) for weed control in soybean (Glycine max) increased the total soluble carbohydrate, lipid and protein contents of the seeds compared to weed free and weedy plots.

\subsection{CONCLUSION}

The herbicides used in the study altered weed flora composition of cowpea plant without having any adverse effect on the nutritional composition of the grains. Thus, the herbicides are recommendable to farmer for 
boosting cowpea production.

\section{REFERENCES}

Adegbite, A.A. and Amusa, N.A. (2008. The major economic field diseases of cowpea in the humid agroecologies of South-Western Nigeria. African journal of Biotechnology 7:4706-4712.

Akobundu I.O. (1987). Weed Science in the Tropics: Principle and Practices. John Wiley \& Sons, New York, $522 \mathrm{pp}$.

Akobundu, I.O. and Agyakwa, C.W (1987). A Handbook of West African Weeds. 2rd ed., International Institute of Tropical Agriculture, Ibadan, $381 \mathrm{pp}$.

Alonge, S.O, ; Ajakaiye, C.O.; Olufajo, O.O. and Lagoke, S.T.O. (1997). Effect of an application of a mixture of metolachlor and metobromuron (Galex) on the biochemical constituents of soybean Glycine max leaves and seeds. Nigerian Journal of Weed Science 10: $49-60$.

AOAC(Association of official Analytical Chemist) (1990). Official Method of Analysis (15th edition. Washigton, D.C., USA.

Arubalueze, C.U., Muoneke, C.O., Remison, S.U., Achebe, U.A., Udeorah, S.N., and Okonkwo, G.I. 2018. Time of introduction of maize/cowpea component crop influenced the performance of cassava/maize/cowpea intercrop. Proc. of 5th Annual Conference, Crop Sci. Soc. of Nigeria, 8-10 Oct., 2018.

Audus, I.J (1980). Herbicides. Vol II second edition. Academic press, London, New York, 564pp

Avav, T and Uza, D.V (2002). Agriculture In: Pageonniere, A.L Les Edition, J.A aux Editions. by du Jaguar Africa Atlases, Atlas of Nigeria, Pris, France, $92-95$.

Chen, W.T (1985). The effect of new herbicides on groundnut and soyabean fields. In: Scientific Meeting report (1984) . Taiwan District Agricultural improvement Station, Taiwan, 29 - 44.

Cousens, R. and Mortimer, M. (1995). Dynamics of weed populations. Cambridge University Press New York, U.S.A, 332pp.

Dugje, I.Y.; Omoigui, L.O.; Ekeleme, F.; Kamara, A.Y. and Ajeigbe, H. (2009). Farmers' guide to cowpea production in West Africa. International Institute of Tropical Agriculture, Ibadan, Nigeria. 24p. Singh, B. B., Ehlers, J. D., Sharma, B. and Freire-Filho, F. R. (2002). Recent progress in cowpea breeding. In: Fatokun, C. A., Tarawali, S. A., Singh, B. B., Kormawa, P. M., Tamo, M. (eds). Proceedings of the world cowpea conference III: challenges and opportunities for enhancing sustainable cowpea production. IITA, Ibadan, Nigeria, pp. 22-40

Dzemo,W.D.; Niba ,A.S.; Asiwe, J.A.N (2010). Introduction to cowpea research production and utilization. African Journal of Biological Technology 9 (11): 165-167.

Hyvönen, T. and Salonen, J. (2002). Weed species diversity and community composition in cropping practices at two intensity levels: a six-year experiment. Plant Ecology 154: $73-81$

Ibedu, M.A.; Unamba, R.P.A. and Udealor, A. (1988). Soil management strategies in relation to farming systems development in the Southeastern agricultural zone of Nigeria. Paper presented at the Natural Farming System Research Workshop Jos, Plateau State, Nigeria, pp. 26-29.

Ighalo, S.O., Okaka, V.B, and Omovbude, S. 2008. Response of maize Zea mays.( L) to different sources of nitrogen fertilizers in a forest - savanna transition zone. Nigerian journal of Agriculture and Forestry $2: 28$ -39 .

IITA (International Institute of Tropical Agriculture) (1982). Selected methods of soil and plant analysis. International Institute of Tropical Agriculture Manual Series No. 7 Ibadan. Nigeria.

Kumar Sit, A.; Bhattacharya M, Sarkar, B and Arunachalam, V (2007). Weed floristic composition in palm gardens in Plains of Eastern Himalayan region of West Bengal Current Science. 92. (10): 1434-1439 .

Osipitan, O. A.; Adigun, J. A. and Kolawole, R. O. (2016). Row spacing determines critical period of weed control in crop: Cowpea (Vigna unguiculata) as a case study. Azarian Journal of Agriculture 3(5): 90-96.

Oyenuga, V.A (1968) Nigeria's Food and feeding stuffs: Their chemistry and nutritive value. Academy press, Ibadan, pp. $41-44$.

Patuibikunle, D.W and Smith M.H (2008), An Economic study of Three villages in Zaria Province to input and output study. Samaru miscellaneous paper 1 (37): 1

Remison, S.U. (2004). Agriculture as the way - Ambik press, Benin - city 73pp.

Singh, B. B.; Ehlers, J. D.; Sharma, B. and Freire-Filho, F. R. (2002). Recent progress in cowpea breeding. In: Fatokun, C. A., Tarawali, S. A., Singh, B. B., Kormawa, P. M., Tamo, M. (eds). Proceedings of the world cowpea conference III, challenges and opportunities for enhancing sustainable cowpea production. IITA, Ibadan, Nigeria, pp. 22-40

Ugbe, L. A.; Ndaeyo, N. U., and Enyong, J. F. (2016). Efficacy of Selected Herbicides on Weed Control, Cowpea (Vigna unguiculata (L). Walp) Performance and Economic Returns in Akamkpa, Southeastern Nigeria. International Journal of Research in Agriculture and Forestry 3 (5) : 19 - 27. 
Table 1: Physiochemical properties of the experimental site before planting

\begin{tabular}{ll}
\hline Soil property & Value \\
\hline Physical Properties & \\
Sand (\%) & 95.0 \\
Silt (\%) & 4.50 \\
Clay (\%) & 0.50 \\
Textural Class & Sand \\
Chemical properties & \\
PH & 6.2 \\
Organic Carbon (\%) & 1.4 \\
Total Nitrogen $(\%)$ & 0.09 \\
Available P (mg/kg) & $15 . .40$ \\
Exchangeable cation (cmol/kg) & \\
K & 0.29 \\
Mg & 2.10 \\
Ca & 3.90 \\
Na & 0.30 \\
Exchangeable Al (cmol/kg) & 0.40 \\
TEA (cmol/kg) & 0.20 \\
ECEC & 0.60 \\
Base saturation $(\%)$ & 7.19 \\
\hline
\end{tabular}

Table 2: Weed flora observed on the experimental site before planting.

\begin{tabular}{|c|c|c|c|}
\hline Plant family & Weed species & $\begin{array}{l}\text { Growth } \\
\text { form }\end{array}$ & $\begin{array}{l}\text { Level of } \\
\text { infestation }\end{array}$ \\
\hline Amaranthaceae & Amaranthus spinosus & ABL & + \\
\hline \multirow[t]{3}{*}{ Asteraceae } & Aspilia africana & $\mathrm{ABL}$ & +++ \\
\hline & Chromolaena adorata & $\mathrm{ABL}$ & + \\
\hline & Emilia praetermissa & $\mathrm{ABL}$ & + \\
\hline \multirow[t]{4}{*}{ Cyperaceae } & Cyperus esculentus & PS & +++ \\
\hline & Cyperus rotundus & PS & +++ \\
\hline & Mariscus alternifolius & PS & ++ \\
\hline & Mariscus flabelliformis & PS & ++ \\
\hline Euphorbiaceeae & Euphorbia heterophylla & $\mathrm{ABL}$ & +++ \\
\hline \multirow[t]{2}{*}{ Fabaceae } & Calapogonium mucunoides & PBL & + \\
\hline & Mucuna pruriens & PBL & +++ \\
\hline \multirow[t]{2}{*}{ Malvaceae } & Malvastrum coromandelianum & PBL & ++ \\
\hline & Sida acuta & $\mathrm{ABL}$ & ++ \\
\hline \multirow[t]{6}{*}{ Poaceae } & Cynodon dactylon & PG & ++ \\
\hline & Eleusine indica & PG & ++ \\
\hline & Imperata cylindrica & $P G$ & ++ \\
\hline & Panicum maximum & PG & ++ \\
\hline & Pennisetum pedicellatum & PG & + \\
\hline & Rottboellia cochinchinensis & PG & + \\
\hline Portulacaeae & Talinium triangulare & PBL & ++ \\
\hline Solanaceae & Solanum nigrum & PBL & + \\
\hline
\end{tabular}

Key: $+++=$ Higher Infestation $(60-90 \%$ occurrence $),++=$ Moderate Infestation $(30-59 \%$ Occurrence $),+=$ Low Infestation ( $1-29 \%$ occurrence) 
Table 3: Weed flora observed on the experimental site at harvest under each treatment

\begin{tabular}{|c|c|c|c|c|c|c|c|c|}
\hline Family & Weed species & $\begin{array}{l}\text { Growth } \\
\text { form }\end{array}$ & W0 & $\mathrm{Cg}$ & $\mathrm{Ga}$ & $\mathrm{Pe}$ & W1 & W2 \\
\hline \multirow[t]{3}{*}{ Asteraceae } & Ageratum conyzoides & $\mathrm{ABL}$ & +++ & + & ++ & ++ & ++ & ++ \\
\hline & Aspilia africana & $\mathrm{ABL}$ & + & + & ++ & ++ & ++ & ++ \\
\hline & Chromolaena adorata & PBL & +++ & + & ++ & ++ & ++ & + \\
\hline \multirow[t]{4}{*}{ Cyperaceae } & Cyperus esculentus & PS & ++ & + & ++ & ++ & ++ & + \\
\hline & Cyperus rotundus & PS & +++ & + & ++ & ++ & + & + \\
\hline & Mariscus alternifolius & PS & ++ & + & ++ & ++ & + & + \\
\hline & Mariscus flabelliformis & PS & ++ & + & ++ & ++ & ++ & + \\
\hline Euphorbiaceae & Euphorbia heterophylla & $\mathrm{ABL}$ & ++ & + & ++ & ++ & ++ & + \\
\hline \multirow[t]{2}{*}{ Fabaceae } & Calapogonium mucunoides & $\mathrm{ABL}$ & + & + & ++ & ++ & + & ++ \\
\hline & Mucuna pruricns & $\mathrm{ABL}$ & ++ & + & ++ & ++ & ++ & + \\
\hline Malvaceae & Sida acuta & PBL & + & + & ++ & ++ & + & ++ \\
\hline \multirow[t]{9}{*}{ Poaceae } & Andropogon gayanus & PG & + & + & ++ & ++ & + & ++ \\
\hline & Chloris pilosa & $\mathrm{AG}$ & ++ & + & ++ & ++ & + & + \\
\hline & Echinochloa colona & $\mathrm{AG}$ & +++ & + & ++ & ++ & ++ & + \\
\hline & Eleusine indica & PG & + & + & ++ & ++ & + & + \\
\hline & Erigeron floribundus & $\mathrm{AG}$ & + & + & ++ & ++ & +++ & +++ \\
\hline & Imperata cylindrica & PG & +++ & + & ++ & ++ & +++ & ++ \\
\hline & Panicum maximum & PG & + & + & ++ & ++ & + & + \\
\hline & Pennisetum pedicellatum & PG & ++ & + & ++ & ++ & + & + \\
\hline & Rottboellia cochinchinesis & PG & +++ & ++ & ++ & ++ & ++ & + \\
\hline Solanaceae & Phyalis angulata & ABL & + & + & ++ & ++ & + & ++ \\
\hline
\end{tabular}

$\mathrm{Wo}=$ no weeding, $\mathrm{Cg}=$ Codalgold $\AA, \mathrm{Ga}=$ Galex, $\mathrm{Pe}=$ Pendilin, W1= hoe weeding once @3 3 WP, W2 = hoe weeding twice@3 and 7WAP,

$+++=$ Higher Infestation $(60-90 \%$ occurrence $),++=$ Moderate Infestation $(30-59 \%$ Occurrence $),+=$ Low Infestation $(1-29 \%$ occurrence $)$

Table 4: Effect of pre emergence herbicides on proximate $(\%)$ and mineral composition $(\mathrm{mg} / \mathbf{1 0 0 g}) \quad$ of cowpea grain.

\begin{tabular}{lllllllll}
\hline Treatment & \multicolumn{9}{l}{ Proximate composition } & \multicolumn{3}{l}{ Mineral composition } \\
\cline { 2 - 8 } & CP & Lipid & Ash & CF & CHO & N & P & K \\
\hline Noweeding (control) & 15.27 & 1.26 & 2.45 & 3.20 & 56.00 & 480 & 441 & 1201 \\
Codalgold@@1.65kg a.i./ha & 23.40 & 1.96 & 3.40 & 3.91 & 56.81 & 517 & 463 & 1261 \\
Galex@3.0 kg a.i./ha & 22.17 & 1.82 & 3.32 & 3.90 & 56.80 & 512 & 460 & 1259 \\
Pendilin@2.0 kg a.i./ha & 22.78 & 1.80 & 3.30 & 3.89 & 56.77 & 510 & 462 & 1255 \\
One hoeweeding@3WAP & 18.56 & 1.29 & 2.92 & 3.60 & 56.64 & 484 & 443 & 1230 \\
Twohoeweeding@3\&7WAP & 20.25 & 1.30 & 3.00 & 3.74 & 56.67 & 495 & 448 & 1250 \\
Mean & 20.41 & 1.57 & 3.07 & 3.71 & 56.62 & 500 & 453 & 1243 \\
\hline
\end{tabular}

$\mathrm{CP}=$ Crude protein, $\mathrm{CF}=$ Crude fibre, $\mathrm{CHO}=$ Carbohydrate, $\mathrm{N}=$ Nitrogen, $\mathrm{P}=$ Phosphorus, $\mathrm{K}=$ Potassium 